\title{
Alteration of blood glucose and hemoglobin levels in zebrafish exposed to sumithion
}

\author{
SI Ahmed ${ }^{1,2}$, MM Zahangir ${ }^{2}$, F Haque ${ }^{3}$, MK Ahmmed ${ }^{2}$, M Shahjahan ${ }^{1, *}$ \\ ${ }^{1}$ Department of Fisheries Management, Bangladesh Agricultural University, Mymensingh-2202, Bangladesh \\ ${ }^{2}$ Faculty of Fisheries, Chittagong Veterinary and Animal Sciences University, Khulshi, Bangladesh \\ ${ }^{3}$ Department of Fisheries Biology and Genetics, Bangladesh Agricultural University, Mymensingh-2202, \\ Bangladesh
}

\begin{abstract}
Sumithion is extensively used in the agricultural land to control brittle and larval rearing aquaculture ponds to control tiger bug. The present study was conducted to evaluate the effects of sumithion on blood glucose and hemoglobin levels in zebrafish, Danio rerio. At first acute toxicity ( $96 \mathrm{~h} \mathrm{LC50}$ value $7.89 \mathrm{mg} / \mathrm{L}$ ) of sumithion was determined for sexually matured zebrafish. Then the fish were exposed to four concentrations $(0,0.5,1.0$ and $2.0 \mathrm{mg} / \mathrm{L}$ ) of sumithion for a period of 7 days. The sexual dimorphic changes in blood glucose levels were observed in the present study. In male, the blood glucose levels were significantly $(\mathrm{P}<0.05)$ increased in all concentrations $(0.5,1.0$ and $2.0 \mathrm{mg} / \mathrm{L})$ of sumithion compared to control $(0 \mathrm{mg} / \mathrm{L})$, while in female the blood glucose levels were significantly $(\mathrm{P}<0.05)$ increased only in high concentration $(2.0 \mathrm{mg} / \mathrm{L})$. Interestingly, the blood glucose level was higher in females than the males of zebrafish. The recorded hemoglobin values were significantly decreased with the increasing concentration of sumithion in both male and female. The present investigation revealed the toxic potentiality of sumithion on the zebrafish.
\end{abstract}

Key words: Pesticide, sumithion, zebrafish, gonad, hemoglobin, blood glucose

Progressive Agriculturists. All rights reserve

*Corresponding Author: mdshahjahan@bau.edu.bd

\section{Introduction}

In Bangladesh, there is a rapid increase in the use of pesticides and herbicides for the growth of high yielding variety crops. Over $98 \%$ of sprayed pesticides and $95 \%$ of herbicides have impacts upon other than their target species, including non-target species, air, water, bottom sediments, and food (Miller and Miller, 2004). Contamination of water by pesticides, either directly or indirectly can lead to fish kills, reduced fish productivity (Talukdar et al., 2012; Rahman et al., 2012; Uddin et al., 2016). Pesticides have been considered as a major contributor of gradual degradation of the aquatic ecosystem including the favorable conditions of fish habitat (Konar and Ghosh, 1982). The pesticides fall under four major groups viz. organochlorine, organophosphate, carbamate and pyrethroid. Sumithion, the O, O Dimethyl O-(3-methyl-4-

nitrophenyl), is an organophosphate insecticide. The effectiveness of sumithion has been found against a wide range of pests, i.e. penetrating, chewing and sucking insect pests on cereals, cotton, orchard fruits, rice, vegetables, and forests. It is also used in larval rearing fish pond to control tiger bug. Sumithion is considered somewhat toxic to fish (Thomson, 1989). The $96 \mathrm{~h} \mathrm{LC50}$ was $1.7 \mathrm{mg} / \mathrm{L}$ for brook trout and 3.8 ppm for bluegill sunfish (Meister, 1994).

As sumithion is widely used for crop protection and for eradication of aquatic insects in aqua-ponds, it is very imperative to know the extent of damage made by this chemical to fish. Different hematological parameters like hemoglobin can be used to find physiological response of contaminated environment (Dethloff et al., 2001). As well as, histopathological 
investigations on different tissues of fish are also valuable tools for toxicology studies (Thophon et al., 2003). In histopathology, we can provide information about the health and functionality of organs. Tissues injuries and damages in organs can result in the reduced survival, growth and fitness, the low reproductive success or increase of susceptibility to pathological agents. Fish exposed to pesticides exhibited a variety of reproductive problems such as reducing number of sperm, abnormal gamete, reducing fecundity (Patyna et al., 1999), sex reversal (Mills and Chichester, 2005), low hatching rate and survivability (Rahman et al., 2002). Hence, it is thought to be worthwhile to conduct a research on the effects of sumithion on the reproductive function in zebrafish.

The zebrafish is one of the most common vertebrate model organisms in genetics, neurophysiology, biomedicine and the developmental biology (Grunwald and Eisen, 2002; Rubinstein, 2003; Shahjahan et al., 2013). It is a small, robust fish, so that a large number of individuals can be kept easily and cheaply in the laboratory, in where it breeds all year rounds. In the present study, an effort was made to examine the toxicity of sumithion to this fish. The changes in blood glucose and hemoglobin levels and gonad morphology were monitored after sub-lethal exposure of this pesticide.

\section{Materials and Methods}

\section{Animals and chemicals}

Sexually mature zebrafish (Danio rerio) were collected from different ponds adjacent to academic building of Fisheries Faculty, BAU. The selected fishes were acclimatized in aquaria at $25 \pm 0.5^{\circ} \mathrm{C}$ under a controlled natural photo-regimen $(14 / 10 \mathrm{~h}$, light/dark) condition for a period of 21 days before the experiments. The fish were fed twice a day with commercial feed. To conduct the present experiment, sumithion $(60 \mathrm{E} / \mathrm{C})$ was collected from retail pesticide shop from local market.

\section{Determination of acute toxicity}

A static acute toxicity bioassay was performed to determine the 24, 48, 72, and $96 \mathrm{~h}$ lethal concentration values (LC50) of sumithion for zebrafish. Seven different concentrations $(4,5,6,7$,
8,9 , and $10 \mathrm{mg} / \mathrm{L}$ ) of sumithion, each having three replications were applied and in control units, sumithion concentration was $0 \mathrm{mg} / \mathrm{L}$. Vigorous aeration was applied to the aquarium for $2 \mathrm{~h}$ in order to obtain a homogeneous concentration of the toxic compound, and then 10 fish were transferred into each aquarium. Mortality was assessed at 24, 48, 72, and $96 \mathrm{~h}$ after the start and dead fishes were removed immediately.

\section{Experimental design, sampling and measurement of blood glucose and hemoglobin}

Twelve aquaria (36 inch $\times 10$ inch $\times 12$ inches) were collected, cleaned, washed and sun-dried properly prior to set in the wet laboratory. Then each aquarium was filled with $20 \mathrm{~L}$ of tap water. Fish were exposed to four concentrations $(0,0.5,1.0$ and 2.0 $\mathrm{mg} / \mathrm{L}$ ) of sumithion each with three replications considering the $96 \mathrm{~h}$ LC50 (7.89 mg/L) value. The application of pesticide at desired concentration was reapplied at every $24 \mathrm{~h}$ with a regular exchange of water. Fish were sacrificed after 7 days of exposure to sumithion. Blood was collected from the caudal peduncle and immediately analyzed for the estimation of glucose $(\mathrm{mg} / \mathrm{dL})$ and hemoglobin $(\mathrm{Hb}$; $\mathrm{g} / \mathrm{dL})$. Blood glucose $(\mathrm{mg} / \mathrm{dL})$ and hemoglobin $(\mathrm{Hb}$; $\mathrm{g} / \mathrm{dL}$ ) were measured by EasyMate ${ }^{\circledR} \mathrm{GHb}$, blood glucose/hemoglobin dual-function monitoring system using glucose and hemoglobin strips.

\section{Statistical analysis}

Values were expressed as means \pm standard deviation (SD). Data were analyzed by one-way analysis of variance (ANOVA) followed by Tukey's post hoc test to assess statistically significant differences among the control and different treated values. Statistical significance was set at $P<0.05$. Statistical analyses were performed using PASW Statistics 18.0 software (IBM SPSS Statistics, IBM, Chicago, USA).

\section{Results}

\section{Acute toxicity of sumithion in zebrafish}

The mortality patterns in relation to sumithion dosages are shown in Table 1. No mortality was taken place in control group. The $96 \mathrm{~h}$ LC50 was calculated by probit analysis (Figure 1). The LC50 
value of sumithion for zebrafish during the $96 \mathrm{~h}$ of exposure was $7.89 \mathrm{mg} / \mathrm{L}$.

\section{Effects of sumithion on blood glucose level}

We examined the blood glucose levels after exposure of fish to sumithion. The sexual dimorphic changes in blood glucose levels were observed in the present study. In male, the blood glucose levels were significantly $(\mathrm{P}<0.05)$ increased in all concentrations $(0.5,1.0$ and $2.0 \mathrm{mg} / \mathrm{L})$ of sumithion compared to control $(0 \mathrm{mg} / \mathrm{L})$, while in female the blood glucose levels were significantly $(\mathrm{P}<0.05)$ increased only in highest concentration $(2.0 \mathrm{mg} / \mathrm{L})$. It is noted that the blood glucose level was higher in female compared to the male of zebrafish (Figure 2).

Table 1. Number of dead fish and their percentage of mortality (in parentheses) in different concentrations of sumithion at different time intervals

\begin{tabular}{cllcccc}
\hline SL & Concentration & Initial No. & \multicolumn{4}{c}{ Exposure time (hours) } \\
\cline { 3 - 6 } No. & $(\mathrm{mg} / \mathrm{L})$ & of fish & 24 & 48 & 72 & 96 \\
\hline 1 & Control & 30 & - & - & - & - \\
2 & 4.0 & 30 & - & - & - & $3(10 \%)$ \\
3 & 5.0 & 30 & - & - & - & $6(20 \%)$ \\
4 & 6.0 & 30 & - & - & $6(20 \%)$ & $9(30 \%)$ \\
5 & 7.0 & 30 & $3(10 \%)$ & $6(20 \%)$ & $9(30 \%)$ & $12(40 \%)$ \\
6 & 8.0 & 30 & - & $6(20 \%)$ & $12(40 \%)$ & $15(50 \%)$ \\
7 & 9.0 & 30 & $3(10 \%)$ & $9(30 \%)$ & $21(70 \%)$ & $27(90 \%)$ \\
8 & 10.0 & 30 & $6(20 \%)$ & $21(70 \%)$ & $27(90 \%)$ & $30(100 \%)$ \\
\hline
\end{tabular}

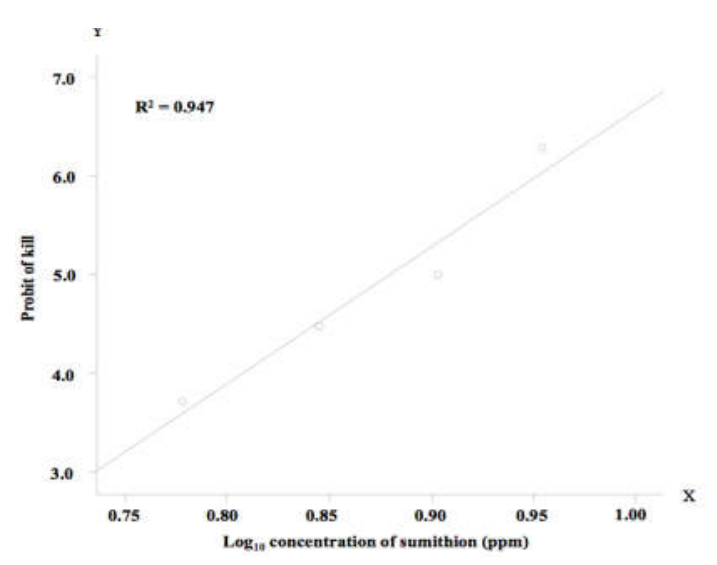

Figure 1. Graph showing the relationship of probit of kill with $\log _{10}$ concentration of sumithion used to deduce the LC50

\section{Effects of sumithion on blood hemoglobin}

In the present study, we examined the effects of sumithion on the blood hemoglobin $(\mathrm{Hb})$. The values of $\mathrm{Hb}(\mathrm{g} / \mathrm{dL})$ were significantly $(\mathrm{P}<0.05)$ decreased with the increasing concentrations of sumithion in both male and female (Fig. 3). The values (means \pm $\mathrm{SD})$ of $\mathrm{Hb}(\mathrm{g} / \mathrm{dL})$ in the male and female of control groups were $13.20 \pm 0.84$ and $13.10 \pm 1.86$, respectively.

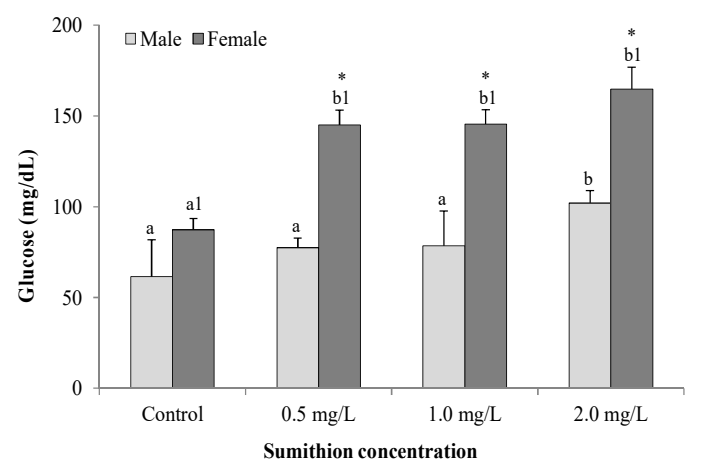

Figure 2. Effects of sub-lethal exposure of sumithion on blood glucose levels (Means \pm SD) after 7 days in zebrafish. Values accompanied by different letters are statistically significantly different $(\mathrm{p}<0.05, \mathrm{n}=4)$. Asterisks denote significant differences among sexes (*, $\mathrm{P}<0.05)$. 


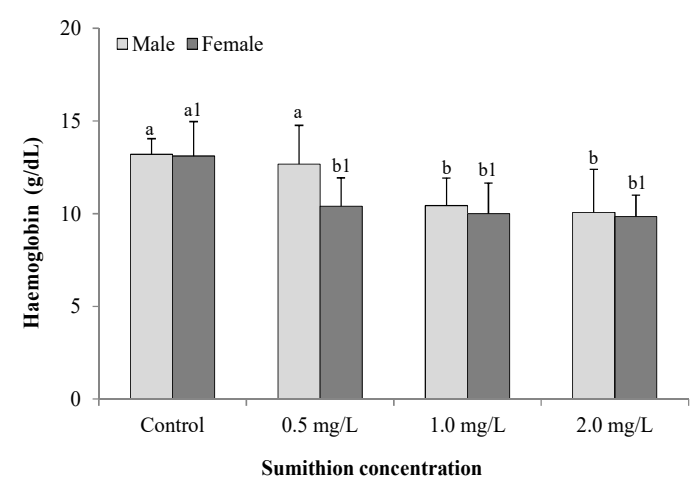

Figure 3. Effects of sub-lethal exposure of sumithion on blood hemoglobin levels (Means \pm SD) after 7 days in zebrafish. Values accompanied by different letters are statistically significantly different $(\mathrm{P}<0.05, \mathrm{n}=4)$

\section{Discussion}

To know the toxic effects of an organophosphorus pesticide sumithion on fish, we examined the effects of sumithion on some hematological parameters and gonad morphology of zebrafish. Differential changes were observed in blood glucose and hemoglobin levels indicating the toxicological impacts of sumithion on fish body.

The $96 \mathrm{~h}$ LC50 value for zebrafish in the present study was lower than other recorded values for different species, such as $9.14 \mathrm{mg} / \mathrm{L}$ for Ptychocheiilus lucius, $11.8 \mathrm{mg} / \mathrm{L}$ for Heteropneustes fossilis, and $15.3 \mathrm{mg} / \mathrm{L}$ for Gila elegance (Durkin, 2008; Faria et al., 2010). On the other hand, lower 96 h LC50 value were recorded, such as $2.2 \mathrm{mg} / \mathrm{L}$ for Nile tilapia and $1.7 \mathrm{mg} / \mathrm{L}$ for brook trout (Meister, 1994; Pathiratne and George, 1998). The variation in the toxicity of the pesticides may be attributed mainly to the susceptibility of the test animals and factors like $\mathrm{pH}$ and hardness of water.

In the present study, the glucose level in both male and female fishes were increased to a significant level due to the exposure of different concentrations of sumithion. The elevated amount of glucose may be due to the high requirement of energy, which increases with the pesticide concentrations. Such increase may be due to enhanced gluconeogenesis response of stressed fish in their attempt to satisfy their new energy demands (Winkaler et al., 2007). More or less similar results were reported in Clarias gariepinus (Abalaka et al., 2011; Mills and Chichester, 2005) and common carp (Hossain et al., 2015). Alterations in blood glucose levels have been reported in Heteropneustes fossilis exposed to sublethal concentration of testosterone (Chowdhury, 2000). This is probably due to the rapid utilization of blood glucose during hyper excitability, tremors and convulsions, which are characteristic behavior of organophosphate pesticide toxicity in fish (Singh and Singh, 1982).

In the present study, the hematological responses of zebrafish in terms of hemoglobin level due to the sub-lethal exposure to sumithion in different concentrations were a significant decrease $(\mathrm{P}<0.05)$ compared to the control group. A similar decreased value of hemoglobin was also reported in common carp exposed to diazinon (Banaee et al., 2011), sumithion (Salam et al., 2015) and Malathion (Sharmin et al., 2015). The concerned decrease in hemoglobin levels in both male and female zebrafish may be due to the disruptive action of the pesticides on the erythropoietic tissue as a result of which the viability of the cells might be affected.

\section{Conclusion}

The current research was conducted to evaluate the effects of sumithion on the blood glucose and hemoglobin levels in zebrafish. Sumithion enhanced the blood glucose level, suggesting that glycogen might be breakdown to glucose due to toxicant of sumithion. Conversely, reduction of $\mathrm{Hb}$ might be because of failing of hematopoietic system. Therefore, the indiscriminate use of pesticide in the field may be a threat to human, fauna and flora of the environment.

\section{Conflict of interests}

The authors declare that they have no conflict of interests. The authors alone are responsible for the content and writing of the paper.

\section{Acknowledgements}

This work was supported by a grant of Impact of Aquaculture Drugs and Chemicals on Aquatic Ecology and Productivity Project (IADCAEPP) 
provided by Bangladesh Fisheries Research Institute (BFRI), Mymensingh-2201, Bangladesh.

\section{References}

Abalaka SE, Esievo KAN, Shoyinka SVO (2011). Evaluation of biochemical changes in Clarias gariepinus adults exposed to aqueous and ethanolic extracts of Parkiabiglobosa pods. African Journal of Biotechnology. 10: 234-240.

Al-kahem Al-Balawi, HF, Ahmad Z, Al-Akel, AS, Al-Misned F, Suliman EM, and Al- Ghanim KA (2011). Toxicity bioassay of lead acetate and effects of sub-lethal exposure on growth, haematological parameters and reproduction in Clarias gariepinus. African Journal of Biotechnology, 10: 11039-11047.

Banaee M, Mirvaghefi AR, Mojazi AB, Rafiee GR, Nematdost B (2011). Hematological and Histopathological effects of Diazinon Poisoning in common carp (Cyprinus carpio). Iranian Journal of Natural Resources, 64: 1-13.

Chowdhury JKP (2000). Effect of administration of testosterone on some biochemical correlates in seminal vesicle of Heteropneustes fossilis (Bloch) during preparatory phase: A study correlating changes in plasma testosterone level and testis activity. Indian Journal of Experimental Biology, 38: 713-719.

Deka S, Mahanta R (2012). A study on the effect of organophosphorus pesticide malathion on heaprenal and reproductive organs of Heteropneustes fossilis. The Science Probe, 1: 1-13.

Dethloff GM, Bailey HC, Maier KJ (2001). Effect of dissolved copper on selected haematological, biochemical and immunological parameters of wild rainbow trout (Oncorhynchus mykiss). Archives of Environmental Contamination and Toxicology, 40: 371-380.

Durkin PR (2008). Malathion: Human Health and ecological risk assessment. Final report submitted to Paul Mistretta, PCR, USDA/Forest Service, Suthern region, Atlanta, Georgia, 325.

Faria IR, Palumbo AJ, Fojut TL, Tjeerdema RS (2010). Water Quality Criteria Report for Malathion. Phase III: Application of the Pesticide Water Quality Criteria Methodology. University of California, DAVIS, 64.
Grunwald DJ, Eisen JS (2002). Timeline-Headwaters of the zebrafish emergence of a new model vertebrate. Nature Reviews Genetics, 3: 717-724.

Hossain S, Khatun MH, Rahman MK, Shahjahan M (2015). Impacts of Sumithion on Blood Glucose and Some Hematological Parameters in Common Carp. International Journal of Environment, 5(1): 8-13.

Konar SK, Ghosh TK (1982). Effects of furadon on fish, plankton, worm and water quality. IAWPC Technical Annual, 9: 128-134.

Magar RS, Blas UE (2013). Histopathological impact of Malathion on the ovary of the freshwater fish Channa punctatus. International Research Journal of Environmental Sciences, 2: 59-61.

Marutirao GR (2013). "Histopathological changes in the ovary of freshwater fish Puntius ticto (Ham) under dimethoate toxicity. An International Quarterly Journal of Life Sciences, vol. 8, pp 989-992, 2013.

Meister RT (1994). Farm Chemicals Handbook. Meister Publishing Co. Willoughby, Ohio, USA. 145-148.

Miller KV, Miller JH (2004). Forestry herbicide influences on biodiversity and wildlife habitat in southern forests. Wildlife Society Bulletin, 32: 1049-1060.

Mills LJ, Chichester C (2005). Review of evidence: are endocrine-disrupting chemicals in the aquatic environment impacting fish population? Science of Total Environment, 343: 1-34.

Pathiratne A, George SG (1998). Toxicity of Malathion to Nile tilapia, Oreochromis niloticus and modulation by other environmental contaminants. Aquatic Toxicology, 43:261-271.

Patyna PJ, Davi RA, Parkerton TF, Brown RP, Cooper KR (1999). A proposed multigenaration protocol for Japanese medaka to evaluate effects endocrine disruptors. Science of Total Environment, 233: 211-220.

Rahman MS, Shahjahan M, Haque MM, Khan S (2012). Control of euglenophyte bloom and fish production enhancement using duckweed and lime. Iranian Journal of Fisheries Science, 11, 358-371.

Rahman MZ, Hossain Z, Mollah, MFA, Ahmed GU (2002). Effects of Diazinon 60EC on Anabas 
testudineus, Channa punctatus, and Barbodes gonionotus. NAGA: The ICLARM Quarterly, 25: 8-11.

Rubinstein AL (2003). Zebrafish: From disease modeling to drug discovery. Current Opinion in Drug Discovery Development, 6: 218-222.

Salam MA, Shahjahan M, Sharmin S, Haque F, Rahman MK (2015). Effects of sub-lethal doses of an organophosphorous insecticide sumithion on some hematological parameters in common carp, Cyprinus carpio. Pakistan Journal of Zoology, 47 (5): 1487-1491.

Shahjahan M, Kitahashi T, Ogawa S, Parhar IS (2013). Temperature differentially regulates the two kisspeptin system in the brain of zebrafish. General and Comparative Endocrinology, 193: 79-85.

Sharmin S, Shahjahan M, Hossain MA, Haque MA, Rashid H (2015). Histopathological Changes in Liver and Kidney of Common Carp Exposed to Sub-lethal Doses of Malathion”. Pakistan Journal of Zoology, 47 (5): 1495-1498.

Singh H, Singh TP (1982). Effect of some pesticides on hypothalamo-hypophyseal-ovarian axis in the freshwater catfish, Heteropneustes fossilis (Bloch). Environmental Pollution, 27: 283-288.
Talukdar MZH, Shahjahan M, Rahman MS (2012). Suitability of duckweed (Lemna minor) as feed for fish in polyculture system. International Journal of Agricultural Research Innovation \& Technology 2(1): 42-46.

Thomson WT (1989). Agricultural Chemicals. Book I: Insecticides. Thomson Publications, Fresno, California. 120.

Thophon S, Kruatrachue M, Upatham ES, Pokethitiyook P, Sahaphong S, Jaritkhuan S (2003). Histopathological alterations of white seabass, Latescarifer, in acute and subchronic cadmium exposure. Environmental Pollution, 121(3): 307-20

Uddin MH, Shahjahan M, Amin AKMR, Haque MM, Islam MA, Azim ME (2016). Impacts of organophosphate pesticide, sumithion on water quality and benthic invertebrates in aquaculture ponds. Aquaculture Reports 3: 88-92.

Winkaler EU, Santos TRM, Machado-Neto JG, Martinez CBR (2007). Acute lethal and sublethal effects of neem leaf extract on the neotropical freshwater fish Prochilodus lineatus. Comparative Biochemistry and Physiology Part C, 145: 236-244. 